\title{
Increasing rice production in sodic soil through ferti-irrigation with distillery spentwash
}

\section{T. BHAGYALAKSHMI, C. A. SRINIVASAMURTHY AND S. BHASKAR}

\section{MEMBERS OF RESEARCH FORUM:}

Corresponding author : T. BHAGYA LAKSHMI, Department of Soil Science and Agricultural Chemistry, University of Agricultural Sciences, GKVK, BENGALURU (KARNATAKA) INDIA

Email: bhagyanagamangala@yahoo.com

Co-authors :

C.A. SRINIVASAMURTHY, Department of Soil Science and Agricultural Chemistry, University of Agricultural Sciences, GKVK, BENGALURU (KARNATAKA) INDIA Email: casmurthy@yahoo.com

S. BHASKAR, Department of Agronomy, University of Agricultural Sciences, GKVK, BENGALURU (KARNATAKA) INDIA

Received : 16.02.2016; Revised : 15.03.2016; Accepted : 11.04 .2016

\section{Summary}

Field experiment was conducted in sodic soil (pH 8. 9 ESP- $31.5 \%$ ) to study the extent of reclamation achieved due to basal application of raw spentwash (RSW) and to study the effect of primary spentwash (SW) used for ferti-irrigation on extent of reclamation incidentally achieved due to spentwash application in comparison with gypsum and also on growth and yield of paddy. Highest grain, straw yield and nutrient uptake was recorded in RSW @ 100\% GR+100\% RDN through SW (3 splits) and lowest was recorded in $\mathrm{T}_{1}$ which received gypsum @ $50 \%$ GR + recommended NPK. Per cent increase in grain yield 47.34 per cent $\left(\mathrm{T}_{9}\right)$ was noticed in spentwash amended plot compared to gypsum treatment $\left(\mathrm{T}_{1}\right)$. Reduction in soil $\mathrm{pH}$ was highest in $\mathrm{T}_{9}$ (RSW @ 100\% GR+100\% RDN through SW (3splits)) and lowest in $\mathrm{T}_{1}$ (Gypsum@50\% GR+ Rec.NPK). Application of RSW @ 100\% GR+100\% RDN through SW (4 splits) recorded significantly lower exchangeable sodium content and ESP compared to other treatments. The cost economics of cultivation revealed that highest benefit cost ratio (2.69) was obtained with raw spentwash @ $100 \%$ GR+ $100 \%$ RDN through treated spentwash in 3 splits while the lowest 0.53 was with gypsum @ $100 \%$ GR+ rec.NPK.

Key words : Distillery spentwash, Ferti-irrigation, Rice production, Soil properties, Cost economics

How to cite this article : Bhagya Lakshmi, T., Srinivasamurthy, C.A. and Bhaskar, S. (2016).Increasing rice production in sodic soil through ferti-irrigation with distillery spentwash. Asian J. Soil Sci., 11 (1): 1-8 : DOI : 10.15740/HAS/AJSS/11.1/1-8. 